\title{
HUBUNGAN HIGIENE PERORANGAN DAN KONDISI FISIK RUMAH DENGAN KEJADIAN PENYAKIT KUSTA (Studi Kasus di Puskesmas Tanjung Bumi Kabupaten Bangkalan Tahun 2019)
}

Tri Agustina Wulansari, Imam Thohari, A.T Diana Nerawati

Jurusan Kesehatan Lingkungan Poltekkes Kemenkes Surabaya Email : triagustinawulansari@gmail.com

\begin{abstract}
ABSTRAK
Pada Tahun 2017 Jawa Timur merupakan provinsi yang paling banyak terdapat kusta dengan jumlah kasus baru sebanyak 3373 jiwa. Salah satu kabupaten yang masih ditemukan kasus kusta baru di Jawa Timur yaitu Kabupaten Bangkalan. Dari beberapa penelitian ventilasi, kelembaban,suhu,kepadatan hunian, jenis dinding, jenis lantai, kebiasaan Mandi, Kebiasaan cuci rambut, kebiasaan tidur bersama-sama, serta memakai pakaian dan handuk secara bergantian diyakini berhubungan dengak kejadian penyakit kusta. Tujuan penelitian ini untuk mengetahui hubungan higiene perorangan dan kondisi fisik rumah dengan kejadian penyakit kusta di wilayah kerja Puskesmas Tanjung Bumi Kabupaten Bangkalan.

Penelitian ini merupakan penelitian observasional analitik dengan pendekatan (case control). Pengumpulan data dilakukan dengan wawancara dan pengukuran kondisi fisik rumah. Besar sampel sebanyak 35 orang kelompok kasus dan 35 orang kelompok kontrol. Data dianalisis melalui uji Chi Square.

Hasil penelitian didapatkan higiene perorangan dan kondisi fisik rumah meliputi pencahayaan, ventilasi berhubungan dengan kejadian penyakit kusta. Sedangkan suhu, kelembaban dan kepadatan hunian tidak berhubungan dengan kejadian penyakit kusta.

Disarankan untuk meningkatkan pola hidup bersih dan sehat dengan tidak menggunakan pakaian,handuk, sabun dengan anggota keluarga yang lain, mencuci rambut secara teratur, serta membuka jendela secara rutin.
\end{abstract}

Kata Kunci : Kusta, higiene perorangan, kondisi fisik rumah

\section{PENDAHULUAN}

Penyakit kusta atau lepra merupakan salah satu penyakit menular yang disebabkan oleh bakteri yaitu Mycobacterium leprae. Masa inkubasi dari kuman ini rata-rata 2-5 tahun bahkan juga dapat memakan waktu lebih dari 5 tahun Penyebaran maupun penularan kuman ini dapat melalui beberapa hal seperti intensitas kontak langsung dengan penderita penyakit kusta (keduanya harus ada lesi baik mikroskopis maupun makroskopis serta adanya kontak yang lama dan berulangulang) dan melalui pernafasan. (Kemenkes RI,2012).

Lingkungan dapat menjadi tempat berkembangbiaknya berbagai macam bakteri, termasuk bakteri patogen. Rumah merupakan bagian dari lingkungan fisik yang berfungsi sebagai tempat tinggal atau hunian, sarana pembinaan keluarga dan sebagian manusia menghabiskan waktunya di rumah. Pada beberapa penelitian menyatakan bahwa kondisi rumah yang kurang sehat dan tidak memenuhi syarat dapat memperparah penyakit dan atau menjadi faktor resiko penularan penyakit menular seperti TBC, ISPA dan juga penyakit Kusta. Kondisi fisik rumah yang tidak memenuhi syarat kesehatan seperti jendela yang jarang dibuka, ventilasi, pencahayaan, kelembaban, suhu, jenis lantai, kepadatan hunian, dan jenis dinding. Selain itu hygiene perorangan juga dapat mempengaruhi terjadinya penyakit kusta seperti Kebiasaan mandi, kebiasaan mencuci rambut, serta memakai pakaian dan handuk secara bergantian (Rismawati,2013;Argiyanti 2014).

Menurut Pusat Data dan Informasi 
Kementerian Kesehatan RI (2018), Indonesia termasuk salah satu negara dengan beban kusta yang sangat tinggi dan menempati peringkat ketiga di dunia sebagai penyumbang kasus baru kusta terbanyak setelah India dan Brasil. Pada tahun 2015-2017 Jumlah kasus kusta baru di Indonesia mengalami penurunan. Pada Tahun 2015 jumlah kasus kusta di Indonesia sebanyak 17.202, Tahun 2016 sebanyak 16.826 dan Pada Tahun 2017 sebanyak 15.920 kasus dengan angka prevalensi sebesar 0,70 kasus $/ 10.000$ penduduk dan angka penemuan kasus baru sebesar 6,08 kasus per 100.000 . Pada Tahun 2017 Provinsi Jawa Timur mempunyai prevalensi penyakit kusta $0,9 / 10.000$ penduduk, sehingga provinsi Jawa Timur telah mencapai status eliminasi kusta akan tetapi jumlah kasus baru kusta di Jawa Timur pada Tahun 2017 masih merupakan jumlah yang terbanyak diantara provinsi lainnya dengan jumlah 3373jiwa.

Kabupaten Bangkalan merupakan salah satu wilayah yang ada di Provinsi Jawa Timur yang masih banyak ditemukan kasus baru setiap tahunnya dengan jumlah kasus baru kusta pada Tahun 2017 sebanyak 263 kasus. Kasus kusta tersebut hampir tersebar diseluruh kecamatan salah satunya yaitu di
Kecamatan Tanjung Bumi dengan jumlah kasus baru kusta pada tahun 2017 sebanyak 22 kasus dan Pada Tahun 2018 sebanyak 16 Kasus baru dan sebagian besar penderita kusta basah. Hal ini menandakan bahwa penularan penyakit kusta masih berlangsung. Tujuan penelitian ini untuk mengetahui Hubungan Higiene peorangan dan kondisi fisik rumah dengan Kejadian Penyakit Kusta.

\section{METODE PENELITIAN}

Penelitian ini menggunakan jenis penelitian observasional analitik, dengan desain penelitian case control. Populasi kasus dalam penelitian ini adalah penderita kusta yang tercatat dalam buku register penyakit kusta di Puskesmas Tanjung Bumi Tahun 20172018 dengan jumlah 38 orang. Sampel yang digunakan dalam penelitian ini terdiri dari sampel kasus dan sampel control dengan perbandingan 1:1 yaitu 35 sampel kasus dan 35 sampel kontrol. Untuk pengambilan sampel dalam penelitian ini menggunakan cara simple random sampling (acak). Data dianalisis dengan menggunakan uji chi-square untuk mengetahui variabel yang berhubungan.

HASIL DAN PEMBAHASAN

Hubungan Higiene Perorangan dengan Kejadian Penyakit Kusta

Tabel 1

HUBUNGAN HIGIENE PERORANGAN DENGAN KEJADIAN PENYAKIT KUSTA

\begin{tabular}{|c|c|c|c|c|c|}
\hline \multirow[t]{2}{*}{ Higiene perorangan } & \multicolumn{2}{|c|}{ Kasus } & \multicolumn{2}{|c|}{ Kontrol } & p-value \\
\hline & $\mathrm{n}$ & $\%$ & $\mathrm{n}$ & o, & \\
\hline Kurang & 21 & 60 & 8 & 22.9 & 0.002 \\
\hline Baik & 14 & 40 & 27 & 77.1 & \\
\hline Total & 35 & 100 & 35 & 100 & \\
\hline
\end{tabular}


Hasil penelitian dengan uji chi-square menunjukkan adanya hubungan antara hygiene perorangan dan kondisi fisik rumah dengan kejadian penyakit kusta ( $p$-value $<a(0,05))$. Hasil penelitian ini juga selaras dengan penlitian Rismawati (2013) yang berjudul Hubungan antara sanitasi rumah dan Personal Hygiene dengan kejadian penyakit kusta Multibasiler menyatakan bahwa terdapat hubungan antara kebiasaan Mandi dan kebiasaan mencuci rambut dengan kejadian penyakit kusta. Sebagian besar responden masih memiliki higiene perorangan yang kurang karena mereka memiliki kebiasaan menggunakan alat pribadi (handuk, pakaian, sabun) dengan anggota keluarga yang lain, jarang menutup hidung dan mulut saat batuk dan bersin, serta kebiasaan mencuci rambut yang kurang dari 2 kali dalam 1 minggu.

Pencegahan penyakit kusta salah satunya dapat dilakukan dengan meningkatkan higiene perorangan, diantaranya seperti pemeliharan kulit yaitu Mandi minimal 2 kali sehari serta menggunakan sabun anti bakteri, tidak menggunakan alat pribadi seperti handuk, sabun, pakaian dan alat makan secara bergantian dengan anggota keluarga yang lain, memiliki kebiasaan menjemur handuk dibawah terik matahari dan menjaga kebersihan rambut seperti mencuci rambut minimal 2 kali dalam seminggu serta memakai shampoo, selain itu menjaga kebersihan tangan dan kuku, kuku harus dalam keadaan pendek dan bersih karena kuku dan tangan yang kotor dapat menimbulkan bahaya kontaminasi ke makanan karena berpindahnya kumankuman pembawa penyakit yang berasal dari tubuh, feses, maupun sumber lainnya. Selain itu pencucian tangan dengan baik dan benar dapat mencegah kontaminasi pada makanan, akan tetapi kegiatan ini sering disepelekan dan masih banyak orang yang kurang mengerti tentang penerapan pencucian tangan (Yuni,2015).

Pentingnya upaya pencegahan penyakit kusta ini melalui higiene perorangan perlu diperhatikan dan dilakukan karena mengingat penularan penyakit kusta dapat melalui kulit dan pernafasan serta terjadi kontak yang lama dan terusmenerus selain itu kuman kusta banyak ditemukan pada daun telinga, kulit tangan dan mukosa hidung yang terdapat pada debu rumah penderita serta juga terdapat dalam air yang biasanya digunakan untuk aktifitas sehari-hari (Cendaki, Q. A,2015).

\section{Hubungan Pencahayaan dengan Kejadian Penyakit Kusta}

\section{Tabel 2}

HUBUNGAN PENCAHAYAAN DENGAN KEJADIAN PENYAKIT KUSTA

\begin{tabular}{|c|c|c|c|c|c|}
\hline \multirow[t]{2}{*}{ Pencahayaan } & \multicolumn{2}{|c|}{ Kasus } & \multicolumn{2}{|c|}{ Kontrol } & \multirow[t]{2}{*}{$p$-value } \\
\hline & $\mathrm{n}$ & $\%$ & $\mathrm{n}$ & & \\
\hline Memenuhi syarat & 8 & 22.9 & 20 & 57.1 & 0.003 \\
\hline Tidak Memenuhi syarat & 27 & 77.1 & 15 & 42.9 & \\
\hline Total & 35 & 100 & 35 & 100 & \\
\hline
\end{tabular}

Hasil penelitian menunjukkan adanya hubungan antara pencahayaan dengan kejadian penyakit kusta ( $\mathrm{p}$-value $<\mathrm{a}$ $(0,05))$. Penelitian ini juga sejalan dengan penelitian Patmawati (2015) yang berjudul Faktor Risiko Lingkungan dan Perilaku Penderita Kusta di Kabupaten Poliwawali mandar bahwa terdapat hubungan antara pencahayaan rumah dengan kejadian penyakit kusta (pvalue $\quad 0,005<0.05$ ). Faktor pencahayaan memiliki hubungan dengan kejadian penyakit kusta. Hal ini terjadi karena cahaya alamiah maupun buatan tidak dapat masuk dan menerangi ruangan dengan sempurna hal ini disebabkan karena jumlah lampu yang digunakan tidak sesuai dengan luas kamar, kondisi lampu yang sudah tidak layak untuk digunakan, kebiasaan 
responden yang jarang membuka tirai pada jendela, serta jendela dan ventilasi yang kurang memenuhi standar kesehatan sehingga hal ini dapat menghalangi cahaya yang masuk.

Rumah yang sehat harus memerlukan penerangan yang cukup dan tidak terlalu banyak. Kurangnya cahaya yang masuk kedalam rumah dapat membuat kurang nyaman dan dapat menjadi media atau tempat yang baik untuk hidup dan berkembangnya berbagai macam mikroorganisme penyebab penyakit (Kusnoputranto dan Suzanna,2000).

Agar intensitas pencahayaan didalam kamar memenuhi syarat bisa dilakukan dengan mengganti lampu yang redup atau menambah lampu agar cahaya bisa menerangi seluruh ruangan, selalu membuka jendela kamar dan pemasangan genteng kaca sehingga cahaya matahari dapat masuk ke ruangan.

Hubungan Ventilasi dengan Kejadian Penyakit Kusta

Tabel 3

HUBUNGAN VENTILASI DENGAN KEJADIAN PENYAKIT KUSTA

\begin{tabular}{|c|c|c|c|c|c|}
\hline \multirow[t]{2}{*}{ Ventilasi } & \multicolumn{2}{|c|}{ Kasus } & \multicolumn{2}{|c|}{ Kontrol } & \multirow[t]{2}{*}{$p$-value } \\
\hline & $\mathrm{n}$ & $\%$ & $\mathrm{n}$ & & \\
\hline Memenuhi syarat & 24 & 68.8 & 21 & 60 & 0.016 \\
\hline $\begin{array}{l}\text { Tidak } \\
\text { syarat }\end{array}$ & 11 & 31.4 & 14 & 40 & \\
\hline Total & 35 & 100 & 35 & 100 & \\
\hline
\end{tabular}

Hasil penelitian menunjukkan adanya hubungan antara ventilasi dengan kejadian penyakit kusta (pvalue $<$ a $(0,05)$. Penelitian ini juga sejalan dengan penelitian Namira (2014) tentang Faktor yang berhubungan dengan kejadian kusta di wilayah kerja Puskesmas Kapita Kabupaten Jeneponto menyatakan terdapat hubungan antara ventilasi dengankejadian penyakit kusta dengan pvalue 0,008. Ventilasi dikatakan berhubungan dengan kejadian penyakit kusta karena dalam penelitian ini rumah responden yang terkena kasus sebagian besar memiliki ventilasi yang kurang memenuhi syarat bahkan ada yang tidak memiliki ventilasi, selain itu ventilasi tersebut tidak berfungsi karena sebagian besar responden khususnya kasus tidak membuka jendela sehingga tidak ada proses pergantian aliran udara yang masuk maupun keluar sehingga dapat menghambat masuknya cahaya alami yang masuk kedalam ruangan, akibatnya ruangan menjadi pengap dan tidak nyaman selain itu akan menjadi tempat perkembangbiakan seperti jamur, virus, dan bakteri, terutama bakteri patoghen seperti bakteri tuberculosis, leprae serta bakteri lainnya. Untuk mendapatkan udara yang cukup didalam rumah sebaiknya cross ventilation dan luas ventilasi yang baik berukuran $10 \%$ sampai dengan $20 \%$ dari luas lantai, membuka jendela secara rutin serta bisa memanfaatkan pohon dan taman yang dapat membantu proses produksi oksigen. Ventilasi yang baik akan memeberikan udara segar dengan suhu optimum $22-24^{\circ} \mathrm{C}$ dan kelembaban $60 \%$ (Kusnoputranto dan Suzanna,2000). 


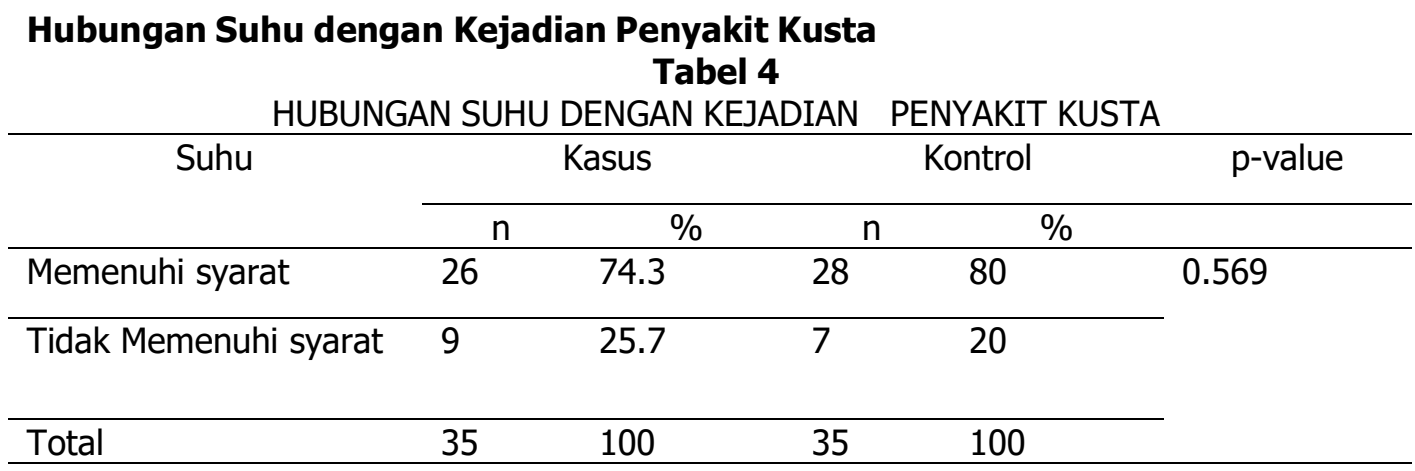

Hasil penelitian khususnya pada kelompok kasus menunjukkan tidak terdapat hubungan antara suhu dengan kejadian penyakit kusta ( $p$ value $>a \quad(0.05))$. Hal ini berbanding terbalik dengan penelitian Rismawati (2013) tentang Hubungan antara Sanitasi Rumah dan Personal Hygiene dengan Kejadian Kusta Multibasiler menyatakan terdapat hubungan antara suhu rumah dengan kejadian penyakit kusta. Kuman kusta yang bertahan hidup lama dalam temperature kamar dapat mempertinggi risiko penularan kusta antar anggota keluarga yang menderita penyakit kusta. Di dalam secret kering dengan temperature dan kelembaban yang bervariasi, M.leprae dapat bertahan hidup 7-9 hari sedangkan pada temperature kamar dapat bertahan hidup sampai 46 hari. Diluar tubuh manusia (dalam kondisi tropis) kuman kusta dari secret nasal dapat bertahan hidup samapai 9 hari. Pertumbuhan optimal in vivo Mycobacterium Leprae pada 1wtikus yaitu pada suhu ruang yaitu $27-30^{\circ} \mathrm{C}$, sehingga hal ini dapat dikatakan bahwa kuman kusta dapat hidup pada suhu udara yang nyaman yang telah ditetapkan oleh pemerintah, akan tetapi kuman kusta dapat tumbuh secara optimal pada suhu $31-37^{\circ} \mathrm{C}$ (Hadi dan Melina, 2017). Upaya penyehatan yang bisa dilakukan jika suhu diatas $30^{\circ} \mathrm{C}$ dengan cara meningkatkan sirkulasi udara dengan menambah ventilasi mekanik atau buatan dan apabila suhu kurang dari $18^{\circ} \mathrm{C}$ dapat dilakukan dengan menggunakan pemanas ruangan dengan menggunakan sumber energy yang aman bagi lingkungan dan kesehatan (Permenkes RI No 1077,2011).

\section{Hubungan Kelembaban dengan Kejadian Penyakit Kusta}

Tabel 5

HUBUNGAN KELEMBABAN DENGAN KEJADIAN PENYAKIT KUSTA

\begin{tabular}{|c|c|c|c|c|c|}
\hline \multirow[t]{2}{*}{ Kelembaban } & \multicolumn{2}{|c|}{ Kasus } & \multicolumn{2}{|c|}{ Kontrol } & \multirow[t]{2}{*}{$\mathrm{p}$-value } \\
\hline & $\mathrm{n}$ & $\%$ & $\mathrm{n}$ & $\%$ & \\
\hline Memenuhi syarat & 22 & 62.9 & 27 & 77.1 & 0.192 \\
\hline Tidak Memenuhi syarat & 13 & 37.1 & 8 & 22.9 & \\
\hline Total & 35 & 100 & 35 & 100 & \\
\hline
\end{tabular}

Hasil penelitian khususnya pada kelompok kasus menunjukkan tidak terdapat hubungan antara kelembaban dengan kejadian penyakit kusta( $p$ value $>$ a $(0,05))$. Hal ini juga sejalan dalam penelitian Ellyke (2012) yang berjudul Kondisi Lingkungan Fisik Rumah Penduduk dengan Kejadian Kusta di Kecamatan Jenggawah Kabupaten
Jember bahwa tidak ada hubungan antara kelembaban dengan kejadian penyakit kusta dengan $p$ value 0,640 . Ruangan dengan kelembaban yang tidak memenuhi syarat dapat menjadi tempat yang baik untuk pertumbuhan mikroorganisme seperti bakteri Mycobacterium Leprae. Menurut $\begin{array}{lll}\text { Kepmenkes RI No } & \end{array}$ 
829/Menkes/SK/VII/1999, kelembaban memenuhi yang syarat yaitu $40-70 \%$. Kuman kusta dapat hidup diluar tubuh manusia dalam kelembaban dan suhu yang bervariasi seperti kelembapan $43,7 \%$ dengan suhu $20,6^{\circ} \mathrm{C}$ kuman kusta dapat bertahan hidup selama 7 hari serta pada suhu $35,7^{\circ} \mathrm{C}$ dan kelembapan $77 \%$ dapat hidup hingga 10 hari. Jadi semakin tinggi kelembaban suatu ruangan, maka semakin lama pula kuman tersebut untuk bertahan hidup di lingkungan.

Upaya penyehatan yang dapat dilakukan menurut Permenkes RI No 1077 Tahun
2011 agar kelembaban didalam rumah memenuhi syarat yaitu jika kelembaban kurang dari $40 \%$ maka dapat dilakukan dengan menggunakan alat untuk meningkatkan kelembaban seperti humidifier (alat pengukur kelembaban udara), membuka jendela rumah, menambah jumlah dan luas jendela rumah, memodifikasi fisik bangunan (meningkatkan pencahayaan dan sirkulasi udara). Jika kelembaban udara lebih dari $60 \%$ maka dapat dilakukan dengan pemasangan genteng kaca.

Hubungan Kepadatan Hunian dengan Kejadian Penyakit Kusta

Tabel 6

HUBUNGAN KEPADATAN HUNIAN DENGAN KEJADIAN PENYAKIT KUSTA

\begin{tabular}{|c|c|c|c|c|c|}
\hline \multirow[t]{2}{*}{ Kepadatan hunian } & \multicolumn{2}{|c|}{ Kasus } & \multicolumn{2}{|c|}{ Kontrol } & \multirow[t]{2}{*}{ p-value } \\
\hline & $r$ & $\%$ & $n$ & o & \\
\hline Memenuhi syarat & 21 & 60 & 25 & 71.4 & 0.314 \\
\hline Tidak Memenuhi syarat & 14 & 40 & 10 & 28.6 & \\
\hline Total & 35 & 100 & 35 & 100 & \\
\hline
\end{tabular}

Hasil penelitian khususnya pada kelompok kasus menunjukkan tidak terdapat hubungan antara kelembaban dengan kejadian penyakit kusta( $p$ value $>$ a $(0,05))$. Hal ini juga sejalan dalam penelitian Ellyke (2012) yang berjudul Kondisi Lingkungan Fisik Rumah Penduduk dengan Kejadian Kusta di Kecamatan Jenggawah Kabupaten Jember bahwa tidak ada hubungan antara kelembaban dengan kejadian penyakit kusta dengan $p$ value 0,640 . Ruangan dengan kelembaban yang tidak memenuhi syarat dapat menjadi tempat yang baik untuk pertumbuhan mikroorganisme seperti bakteri Mycobacterium Leprae. Menurut Kepmenkes RI No 829/Menkes/SK/VII/1999 Kelembaban memenuhi yang syarat yaitu $40-70 \%$. Kuman kusta dapat hidup diluar tubuh manusia dalam kelembaban dan suhu yang bervariasi seperti Kelembapan $43,7 \%$ dengan suhu $20,6^{\circ} \mathrm{C}$ kuman kusta dapat bertahan hidup selama 7 hari serta pada suhu $35,7^{\circ} \mathrm{C}$ dan kelembapan $77 \%$ dapat hidup hingga 10 hari. Jadi semakin tinggi kelembaban suatu ruangan, maka semakin lama pula kuman tersebut untuk bertahan hidup di lingkungan. Upaya penyehatan yang dapat dilakukan menurut Permenkes RI No 1077 Tahun 2011 agar kelembaban didalam rumah memenuhi syarat yaitu jika kelembaban kurang dari $40 \%$ maka dapat dilakukan dengan menggunakan alat untuk meningkatkan kelembaban seperti humidifier( alat pengukur kelembaban udara), membuka jendela rumah, menambah jumlah dan luas jendela rumah, memodifikasi fisik bangunan (meningkatkan pencahayaan dan sirkulasi udara). Jika kelembaban udara lebih dari $60 \%$ maka dapat dilakukan dengan pemasangan genteng kaca .

Hasil penelitian khususnya pada kelompok kasus menjukkan tidak terdapat hubungan antara kepadatan hunian dengan kejadian penyakit kusta pvalue $>a(0,05)$. Hal ini tidak sejalan dengan penelitian Namira (2014) tentang Faktor yang berhubungan dengan kejadian kusta di wilayah kerja Puskesmas Kapita Kabupaten Jeneponto 
menyatakan terdapat hubungan antara kepadatan hunian dengan kejadian kusta dan dan pvalue sebesar 0,001. Menurut Kepmenkes RI No 829/Menkes/SK/VII/1999 bahwa persyaratan kepadatan hunian rumah tidur yaitu memiliki luas ruang tidur minimal $8 \mathrm{~m} 2$ dan tidak dianjurkan digunakan lebih dari 2 orang tidur dalam satu ruang tidur kecuali anak dibawah umur 5 tahun. Ruangan yang dihuni oleh banyak orang dan tidak sebanding dengan luas kamar akan memberikan dampak bagi penghuninya yaitu membuat rumah menjadi sempit selain hal itu apabila dalam suatu rumah tersebut terdapat anggota keluarga yang terkena penyakit maka penularan penyakit tersebut akan sangat mudah menular ke anggota keluarga yang lain akibat seringnya kontak fisik dengan si penderita.

\section{KESIMPULAN}

Terdapat hubungan antara higiene perorangan, pencahayaan dan ventilasi dengan kejadian penyakit kusta dan tidak ada hubungan antara suhu, kelembaban dan kepadatan hunian dengan kejadian penyakit kusta.

\section{SARAN}

1. Bagi Institusi Terkait (Puskesmas) : Memberikan penyuluhan mengenai penyakit kusta dan upaya pencegahannya khususnya dalam perbaikan higiene perorangan dan lingkungan fisik rumah penderita.

2. Bagi Masyarakat

a. Diharapkan kepada masyrakat khususnya penderita kusta untuk meningkatkan pola hidup bersih dan sehat dengan meningkatkan serta menjaga kebersihan diri seperti tidak memakai pakaian, handuk dan sabun secara bergantian dengan anggota keluarga yang lain, mencuci rambut secara teratur serta membuka jendela setiap hari.

b. Rajin mengkonsumsi obat serta melakukan pemeriksaan dini ke puskesmas apabila terdapat bercak yang menyerupai panu maupun gejala lainnya yang mirip dengan penyakit kusta untuk memastikan apakah gejala tersebut merupakan gejala dari penyakit kusta.

c. Bagi peneliti lain Dapat dijadikan sebagai referensi tambahan dan data dasar penelitian sejenis dan melakukan penelitian lebih lanjut mengenai faktor-faktor yang dapat mempengaruhi terjadinya penyakit kusta.

\section{DAFTAR PUSTAKA}

Argiyanti,D.2014. Hubungan Lingkungan Fisik Rumah dengan Penyakit Kusta di Wilayah Kerja Puskesmas Kabunan Kabupaten Pemalang [Skripsi]. Surakarta : Kesehatan Masyarakat,Fakultas Ilmu Kesehatan.

Ellyke. 2012. Kondisi Lingkungan Fisik Rumah Penduduk dengan Kejadian Kusta di Kecamatan Jenggawah Kabuapten Jember.Jurnal IKESMA Volume 8 Nomor 2

Hadi \& Melina.2017. Kusta Stadium Sub Klinis Faktor Risiko dan Permasalahannya. Surabaya : Program Studi Arsitektur UIN Sunan Ampel

Kusnoputranto dan Suzanna,2000. Kesehatan Lingkungan. Jakarta : Fakultas Kesehatan Masyarakat,Universitas Indonesi

Kemenkes RI. 2012. Pedoman Nasional Program Pengendalian Penyakit Kusta. Kementerian Kesehatan RI Direktorat Jenderal Pengendalian Penyakit Dan Penyehatan Lingkungan. Jakarta

Keputusan Menteri Kesehatan RI No.829/Menkes/SK/VII/1999.

Tentang Persyaratan Kesehatan Perumahan

Namira.2014. Faktor yang Berhubungan dengan Kejadian Kusta di Wilayah Kerja Puskesmas Kapita Kabupaten Jeneponto[Skripsi].Makassar:Fakulta s Ilmu Kesehatan, Universitas Islam Negeri Alauddin Makassar

Patmawati,2015. Faktor Risiko Lingkungan dan Perilaku Penderita Kusta di Kabupaten Polewali Mandar,Buletin Penelitian Kesehatan, Vol.43,No.3 September 
$2015: 207-212$

Pusat Data dan Informasi Kementerian Kesehatan RI. 2018. Hapuskan Stigma dan Diskriminasi Terhadap Kusta. Infodatin Kusta.pdf.

Permenkes RI

Nomor

1077/MENKES/PER/V/2011 Tentang Pedoman Penyehatan Udara dalam Ruang Rumah
Rismawati, Dwina.2013.Hubungan Antara Sanitasi rumah dan Personal Hygiene dengan Kejadian Kusta Multibasiler. Jurnal Vol. 2 No. 1 Tahun 2013 Jurusan Ilmu Kesehatan Masyarakat, Universitas Negeri Semarang

Yuni. 2015. Buku Saku Personal Hygiene.Yogyakarta :Nuha Medika 